\title{
THE EFFECTS OF KNOWLEDGE CHARACTERISTICS, ORGANIZATIONAL AND SOCIETAL CULTURE IN KNOWLEDGE TRANSFER WITHIN FIRMS
}

\author{
DOI: 10.17261/Pressacademia.2019.1081 \\ PAP-V.9-2019(28)-p132-143
}

Naciye Guliz Ugur ${ }^{1}$, Aykut Hamit Turan², Karen Moustafa Leonard ${ }^{3}$

${ }^{1}$ Sakarya University, Department of Management Information Systems, Sakarya, Turkey ngugur@sakarya.edu.tr, ORCID: 0000-0003-2364-5445

${ }^{2}$ Sakarya University, Department of Management Information Systems, Sakarya, Turkey ahturan@sakarya.edu.tr, ORCID: 0000-0002-8855-4643

${ }^{3}$ University of Arkansas Little Rock, Department of Management, Little Rock, AR, USA kxleonard@ualr.edu, ORCID: 0000-0002-6299-6427

\section{To cite this document}

Ugur, N.G., Turan, A.H., Leonard, M.,(2019). The effects of knowledge characteristics, organizational and societal culture in knowledge transfer within firms. PressAcademia Procedia (PAP), V.9, p.132-143

Permemant link to this document: http://doi.org/10.17261/Pressacademia.2019.1081

Copyright: Published by PressAcademia and limited licenced re-use rights only.

\begin{abstract}
Purpose- Knowledge is a competitive asset for the firm. Yet, existing studies mostly investigated joint ventures, acquisitions, and cross border transfers not knowledge transfer at the micro level per se. Hence, individual to individual transfer within a single firm present importance. In this study, we examine the transfer methods and possible inhibitors among individuals in organizations.

Methodology- In this study, we have presented an individual knowledge transfer framework. This framework is personal, and transfer is also a social event. Organizational and societal culture aspects are also incorporated in the framework. The proposed framework could allow future studies new pleasurable directions

Findings- The proposed framework and propositions are taught to be quite useful in research and managerial areas and could provide a significant contribution to scholarly publications that would be carried out in the future. We also suggest future research directions in examining micro-level knowledge transfer that also could provide an important competitive advantage to a firm.

Conclusion- Effective and efficient knowledge transfer provides a competitive advantage to the firm. Therefore, it is crucial firms decide and implement how, when, where, and why employees transfer needed knowledge within the firm. This framework could enable firm managers to appreciate and consider all important dimensions of knowledge transfer and better facilitate the micro level knowledge transfers within firms.
\end{abstract}

Keywords: Knowledge management, knowledge transfer, theoretical study, framework development, organizational culture JEL Codes: D23, D21, D83

\section{INTRODUCTION}

Over the past few decades, most of the research on knowledge management has been concentrated on transfer from one company to another or from one subsidiary to another, primarily focusing on joint ventures, acquisitions, and transfer across firm borders (c.f., (Fletcher \& Harris, 2012; Sarala, Junni, Cooper, \& Tarba, 2016; Esposito \& Evangelista, 2016). Although knowledge management using technology has been found to be unsuccessful or to have unsubstantiated success (c.f., (Buehrer, Senecal, \& Bolman, 2005), others consider it to simply be a fad (c.f., (Lorrich, Pierce, \& John, 1984). However, other authors have developed a view of the firm that considers knowledge to be a competitive advantage (c.f., (Barney, 1991; Frappaolo, 2006). This competitive advantage requires agility, e.g., the need for "employees to continually develop, use, and share knowledge," and for the organization to respond by "encouraging, taking up, and making effective use of" this knowledge (BenMoussa, 2010, p. 303). Pauluzzo and Cagnina (2017) examined cultural competencies in knowledge transfer in their case study, proposing a framework to help transfer, although their premise was quite different from the one presented here.

Wilson (2002) considered knowledge management to be "nonsense," because the distinction between knowledge and information has not been clear, and most firms simply use it as a term for work practices. He went so far as to term it as "consultant-driven" and, therefore, a waste of firm time and money. Although other authors do not take their critiques this far, knowledge management has proven to be an elephant, where your view depends upon which part you examine. In this paper, knowledge management is considered a valuable resource within individual workers that creates competitive advantage for the firm. 
This paper reflects a micro approach to knowledge transfer, considering how organizational knowledge, as differentiated from data and information, is exchanged from one employee to another.

Methods of transfer are explored, and a framework with hypotheses are presented, using literature in knowledge characteristics, organizational culture and societal culture. Conclusions expand the concepts of knowledge transfer within the framework, and future research suggestions include investigation of knowledge transfer between various levels of the organization and across cultural segments of the firm.

\section{LITERATURE REVIEW}

Definitional problems persist in understanding data, information, and knowledge, with many people mistakenly considering them to be the same. The differences among data, information, and knowledge have been outlined in various papers and books (c.f., (Berger \& Luckmann, 1966; Gourlay, 2006; Nonaka, 1994) ), so it is only briefly reviewed here. As observed by Bhagat, Kedia, Harveston, and Triandis (2002, pp. 205-206):

Knowledge is broader, deeper, and richer than data or information. Data reflects discrete, objective facts about events in our world, while information is organized around a body of data...Knowledge is created, restructured, or changed from related and unrelated pieces of information, to the extent that the information has the right kinds of signals that ... are conducive to the creation of knowledge.

Knowledge is a deeper use of data and information because they are used within a particular context. Over time, it has become clear that knowledge exists only within the individual, i.e., knowledge is intellectual capital (e.g., (Drucker P. F., 1999; Martensson, 2000; Ringberg \& Reihlen, 2008).

Truly valuable knowledge is tacit, or personal knowledge, held within individuals (Alavi \& Leidner, 2001; Nonaka \& Konno, 1998), or intrinsically present in organizational members in highly specialized ways (Grant, 1996a) In effect, individuals have the knowledge upon which the organization depends, as these employees create, develop, and possess that knowledge which sustains and advances the organization. The daunting challenge for contemporary knowledge management is the conversion of individual knowledge into organizational knowledge to the greater benefit of the entire business enterprise. The pursuit of knowledge, unfortunately, may be somewhat elusive to knowledge management practitioners regardless of their diligence. Weick (2001) reiterated that, in any situation, all the potential knowledge concerning any circumstance is never known, and the knowledge available to the organization may well be fallible.

Davenport and Prusak (2000) defined tacit knowledge valuable to the firm as "a fluid mix of framed experiences, values, contextual information, and expert insight that provides a framework for evaluating and incorporating new experiences and information" (p. 5). Firms such as McKinsey and Company consider knowledge to be personalized and concentrate on the human capital within the organization rather than on technology (Hansen \& Nohria, 1999). Individual's knowledge allows competent action (Argyris \& Schon, 1978; Diakoulakis, Georpopoulos, Koulouriotis, \& Emeris, 2004; Nonaka \& Takeuchi, 2004).

This concept of knowledge as personalized fits within both the resource based (Penrose, 1959) and the knowledge based views of the firm (c.f., (Griffiths \& Remenyi, 2008; Stewart, 1997; Sveiby, 1999). The resource-based view of the firm suggests that human resources are valuable because their knowledge and understanding provide competitive advantages, particularly by being difficult to copy or substitute (Barney, 1991; Wright, McMahan, \& McWilliams, 1994). The knowledge based view holds that strategic competitive advantage is available from the knowledge, or intellectual capital, held within the brains of employees (c.f., (Berger \& Luckmann, 1966; Drucker P. F., 2010; McDermott, 1999), and others emphasize that knowledge is the most valuable firm resource because of its ability to create sustainable competitive advantage (Cohen \& Levinthal, 1990; Tobin, 1997).

Tacit knowledge is extremely difficult to codify, because of its personal nature (Scarbrough \& Swan, 1999). Some consider tacit, personalized knowledge useless, because it is often difficult to explain, such as the knowledge used to walk; e.g., it takes a great deal of time to reteach someone to walk again. It also requires that the person who is transferring the tacit knowledge be motivated to share it (DeSouza, 2003). Brauner and Becker (2006) found that knowledge is related to one's thinking, reasoning, and memory, and because it is passive in nature, it disappears or dissolves if not spread. Human relationships are the key to knowledge transfer within organizations (Lang, 2001; McCann \& Syke, 2004), with both societal and organizational culture being key aspects influencing knowledge transfer (Lukas \& Ogilvie, 2006; Schein, 2010).

\subsection{Knowledge Management Techniques}

The idea of knowledge management derives from the fact that humans and organizations cannot use all of the knowledge that they have available at a given time (King W. R., 2009). The other side of that problem is that "the organization does not know what it knows" (O'Dell \& Grayson, 1998, p. 154). Knowledge management techniques depend upon the definition of knowledge. Those considering knowledge as information use computer-mediated techniques. These are often only marginally successful at best, and only a few success stories provide anecdotal evidence of success (Buehrer, Senecal, \& Bolman, 2005; Ekbia \& Hara, 2008; Lin, Yeh, \& Tseng, 2005).

Technological retention of knowledge is not a competitive advantage, as it is highly imitative (McCann \& Syke, 2004). The benefit of information systems is that they can deal with extremely large sets of data and/or information that can then be used in appropriate situations to create knowledge (Hansen \& Nohria, 1999). However, the drawback is that large databanks (Big Data) make it hard to access the specific pieces of data or information needed in a given situation (McCann \& Syke, 2004). Many companies continue to consider knowledge management as a technical issue (KMPG, 2000). They expect knowledge to be a 'commodity' available explicitly within the confines of technology (Storey \& Barnett, 2000). For example, the consulting firm of Ernst and Young continue to attempt to codify knowledge, i.e., put knowledge within computers (Hansen \& Nohria, 1999). Buehrer, Senecal, and Bolman (2005) found that 70 percent of knowledge 
management programs used in sales are unnecessary. Even success stories of codifying tacit knowledge are questioned for lack of evidence (c.f., (Buehrer, Senecal, \& Bolman, 2005; Ekbia \& Hara, 2008; Lucier, 1997).

The technocratic perspective is based primarily upon information technologies that are deployed to support individuals in their daily tasks, routines, and specific work assignments (Bassi, 1997; Davenport, De Long, \& Beers, 1998). The technocratic or information-based approach is predicated upon making knowledge more manageable by "capturing, archiving, tracking, synthesizing, and diffusing information" (Reis \& Clohesy, 1999, p. 11). The technocratic perspective is commonly referred to as the information technology or IT approach to knowledge management, due to its overwhelming dependency upon vast computer systems and automated processes to manage knowledge effectively.

However, many researchers studying knowledge management consider organizations to be within a social collective (c.f. (Wadell, Bjork, \& Magnusson, 2014) and to be a very complex system which exists "through the use of information and energy" (Yolles, 2006) p. 3). Yolles stated that knowledge is collected through individual employees, unstable, and subject to change. As a human endeavor, knowledge transfer takes time and effort (Du Plessis, 2005; Keen \& Mackintosh, 2001), which could be a component helping to create a perceived lack of usefulness in some instances (c.f., (Du Plessis, 2005; Lukas \& Ogilvie, 2006).

Scarbrough and Swan (1999) explained that tacit knowledge might seem to be messy, naïve, inaccurate, or irrelevant in a dynamic environment, lessening its perceived value. It can also be tentative and have different interpretations, based on the individual's context when creating the knowledge for a specific use (Popper, 1979). It is kept only semiconsciously, which prevents its automatic transfer (Nonaka \& Takeuchi, 1995; Polanyi, 1966). However, once embedded, tacit knowledge seems effortless, which may allow a perception that it is of low value to the firm (Grayson \& O'Dell, 1998; Leonard-Barton \& Sensiper, 1998; Polanyi, 1966).

Knowledge transfer involves an expectation of exchange (Argote, Ingram, Levine, \& Moreland, 2000; Foa \& Foa, 1980), but few firms provide incentives to motivate individuals to take the time and effort to transfer knowledge. The idea of giving away key expertise learned on the job can be viewed as a loss of power (Frappaolo, 2006). In some firms, being considered an 'expert' may limit opportunities for advancement, as individuals can be considered too valuable to be promoted (DeSouza, 2003). Tacit knowledge includes "intangible factors embedded in personal beliefs and values" (Pan \& Scarbrough, 1999, p. 362), and this is one of the factors inhibiting transfer (Hudson, 2002).

Transferring knowledge means that values, beliefs, and behavioral scripts are shared between employees, and only knowledge deemed useful to the organization is shared (Kashima, 2014). Transfer occurs person to person during social interaction (Wenger, 1998), creating intrinsic value (Evetts, 1999). Knowledge transfer may become a part of the individual's perceived identity (Evetts, 1999). The organizational culture, then, determines what information will be shared and with whom (Baumeister \& Leary, 1995; Gardner, Pickett, \& Brewer, 2000; Schein, 2010). However, trust within the culture is essential to knowledge transfer and, in firms with low trust among members, knowledge will concentrate in only a few employees, reducing competitive advantage (Kucharska \& Kowalczyk, 2016; Sankowska, 2016).

Essential knowledge is transferred and accepted because it gives meaning to those who receive it (Kashima, 2014), allows them to act appropriately by reducing uncertainty (Chou, Hong, \& Chiu, 2012; Gelman, 2003; Medin, 1989). This type of knowledge transfer allows the continuation of processes, ideas, procedures, and visions within the boundaries of the company, although sometimes there are also crossborder transfers to other companies (e.g., when people are laid off and hired by another company). However, these moves are counterproductive, and lessens the firm's competitive advantage.

Knowledge transfer promotes group or team cohesiveness among group members (Morton \& Postmes, 2009; Morton, Postmes, Haslam, \& Hornsey, 2009). Using knowledge transfer of prevalent beliefs (culture) among members allows a group or organization to identify itself as unique and different from other groups, strengthening the group or organizational identity and individual commitment (Fischer, 2011; Gelman, 1988; Gelman, 2003; Jayaratne, et al., 2006; Prentice \& Miller, 2006). Therefore, promoting knowledge transfer in organizations can create a strategic competitive advantage (Syed-Ikhsan \& Rowland, 2004).

Cultures and organizations differ in knowledge management techniques due to the dissimilarity of their knowledge base. Attainment of knowledge is a constant process, in that existing knowledge permits organizations to create new knowledge (Becerra-Fernandez \& Sabherwal, 2001; Conner \& Prahalad, 1996). The competitiveness of a firm to incorporate an individual's knowledge within in its workforce distinguishes it from other businesses in terms of its position and leadership in the market (Grant, 1996b). If an organization values and practices knowledge management, it will have greater success than those that are resistant to change or do not apply knowledge management in accordance to their environment. All these characteristics of knowledge led Drucker (1994) to conclude that knowledge is a valuable asset for any organization, even though it is not easily quantified on the balance sheet.

\section{A FRAMEWORK OF KNOWLEDGE TRANSFER}

As knowledge consists of myriad constructs or models, the same is true for knowledge management. Branch (1997) characterized knowledge management as a complex socio-technical system that embraces myriad forms of knowledge creation, generation, sharing, and storage. Armbrecht et al. (2001) maintained that knowledge management is merely doing what is required to get the most out of knowledge resources, as it focuses on organizing, structuring, and making important knowledge available (Sabherwal \& Becerra-Fernandez, 2003). There is some concern whether knowledge transfer can actually occur, because it is not known how much individuals understand each other, because each has their own mental model of the world (Rescher, 1998).

Taking the ideas from the above discussion of knowledge as a social construction, a framework of transfer was developed. One of the most essential aspects of knowledge management is knowledge transfer from one person to the other within the organization (Alavi \& Leidner, 2001; Earl, 2001; Hendricks, 1999). The framework proposed in Figure 1 represents a preliminary model indicating knowledge transfer processes and potential moderating variables. 
Figure 1: Model of Individual Knowledge Transfer

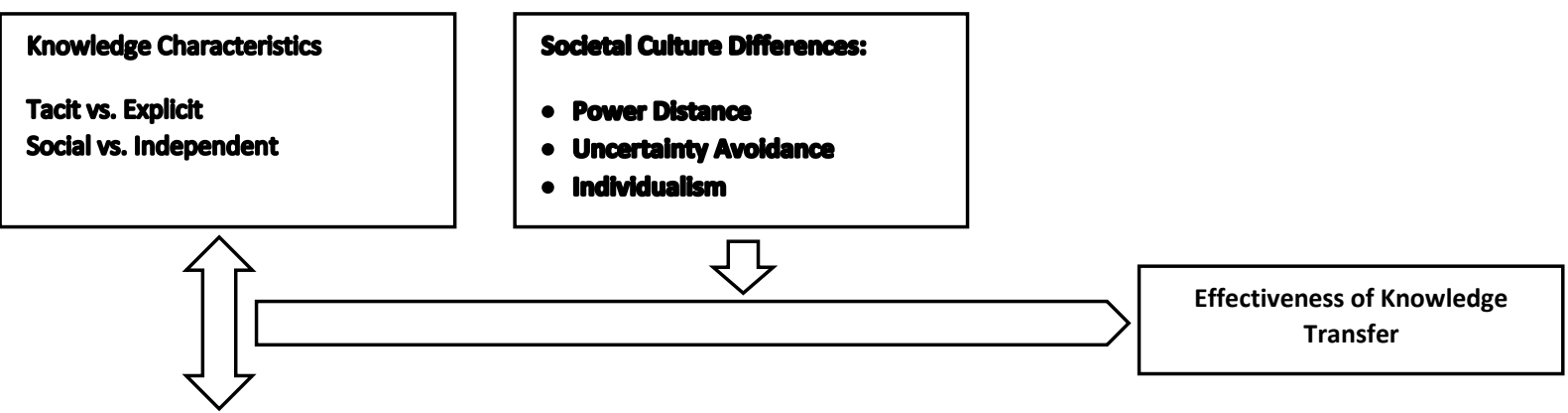

Antecedent Organizational Culture
Hierarchy
Market
Clan
Adhocracy

\subsection{Knowledge Characteristics}

Knowledge characteristics are those things that set knowledge apart from data and information. Davenport and Prusak (2000) outlined those elements needed to consider an individual's 'thought' as actual knowledge: originating from individual experiences and learning, often imbedded within an individual, used within a context. This indicates that knowledge encapsulates information and data but is used to solve specific problems.

Prominent researchers may provide differing characterizations and insights into the various basic knowledge constructs. Stenmark (2000/2001) asserted that all knowledge is pluralistic and represents a network of interrelated organizational activities while being reflective of individuals' social behaviors. From an anthropological perspective, Barth (2002) posited knowledge as our interpretative understanding of experiential learning and synthesized information as well as our innate appreciation of attitudes, skills, and recognized realities. Similarly, Davenport and Prusak (2000) characterized knowledge as a composite of framed experiences and related information, coupled with expert insights that serve as the basis for further synthesis of new experiences and information. The authors maintained that while knowledge originates with the knower, it is developed, applied, and shared through myriad organizational documents and repositories thereby facilitating the organization's knowledge management process.

From a candidly business perspective, Leonard and Sensiper (1998) simply described knowledge as the pertinent information utilized by the organization that is partially experience-based. Clearly, experiential learning and individual experiences are the common threads that unite these knowledge constructs. Employers consider knowledge to be what they understand (De Long \& Fahey, 2000), what they know, and what they know how to do (Bhagat, Kedia, Harveston, \& Triandis, 2002). In organizations, knowledge within employees can be shared and combined to become social or collective knowledge, composed of norms created by working together, or structured knowledge, found in such artifacts as processes, and routines (De Long \& Fahey, 2000). Polanyi (1958) discusses the complexity of knowledge, stating that individuals know more than they are able to tell.

Simple knowledge is easily transferred, but complex knowledge, tied to many aspects of the organization, including processes, rules, and organizational culture, is not easily transferred from one person to another (Polanyi, 1958; Polanyi, 1969). Organizational knowledge is generally interdependent or systemic knowledge, that is, it is based on the interconnecting work patterns and relationships within the firm and requires understanding of the organization to be useful (Bhagat, Kedia, Harveston, \& Triandis, 2002). Tacit, social knowledge is of high value to the firm, but difficult to put into explicit form. Therefore, we propose:

Proposition 1: Transfer of tacit, social knowledge of value to the firm is more successful when there are interconnecting communication patterns throughout the firm.

\subsection{Overview of Culture}

Culture is the series of assumptions belonging to group of individuals (Hofstede, Hofstede, \& Minkov, 2010), and defines how individuals feel, think and act (Triandis, Cross-cultural industrial and organizational psychology, 1994). It is like a mental code that programs each person in perceiving reality and the appropriate behaviors and responses to the environment and termed "software of the mind" by Hofstede (Hofstede, Hofstede, \& Minkov, 2010). He meant that culture is collective programming of each mind, creating differences on the assumptions of group of people to another. Culture differs from person to person and nation to nation and plays significant roles in shaping organizational strategies and policies.

Culture can be viewed in both a macro and micro perspective. In a macro sense, even though different countries have changing cultures, practices unify and harmonize diversity since the phenomenon of globalization directed and authorized by ever-changing technologies makes such incorporation a requirement. In a micro sense, when such transfer of knowledge is internalized through a process of sharing within the 
members of an organization, it acquires the characteristics of organizational culture (Nonaka \& Takeuchi, 1995). Two types of culture are considered here as having effects on knowledge transfer: Organizational and societal cultures.

\subsection{Organizational Culture}

Organizational culture permeates the social fabric of the business enterprise, yet its properties are difficult to appraise with certainty. There is an indivisible relationship between organizational culture and knowledge management (Davenport \& Prusak, 2000; Nonaka \& Takeuchi, 1995; von Krogh, Ichijo, \& Nonaka, 2000). Alavi and Leidner (2001) maintained that the success of knowledge management and the effectiveness of knowledge sharing in organizations are predominately associated with organizational culture. The researchers posited that organizational culture is intimately related to knowledge management and that successful deployment initiatives are dependent upon the culture, management, and the organization itself. Hackett (Hackett, 2000) noted that organizations with successful knowledge management initiatives frequently cited their inherent culture as the crucial factor behind their achievement. In fact, business culture may be the determining factor with respect to lofty organizational goals and objectives for knowledge management initiatives (Davenport \& Prusak, 2000).

There is little empirical literature regarding the effect of organizational culture on knowledge transfer (Gray \& Densten, 2005), although later research by Al-Alawi, Al-Marzooqi, and Mohammed (2007) demonstrate that positive organizational culture characteristics improve knowledge management. This aligns with Janz and Prasarnphanich's theoretical model, indicating that organizational culture affects knowledge management. Gray and Denison developed a macro framework, the Organizational Knowledge Management model, using the Competing Values Framework developed by Cameron and Quinn (1999) along with the Knowledge Creation Spiral (Nonaka and Takeuchi, 1995). The authors confirmed the positive effect of culture on variables related to knowledge transfer, such as externalization, internalization, and socialization. But this was not consistent, varying with each cultural factor.

Inter-professional and intra-organizational work requires sharing diverse types of knowledge (Carrier \& Kendall, 1995). However, as with knowledge transfer between firms, individuals can accept only particular knowledge and amounts of knowledge. The particular knowledge that they can accept depends, as discussed above, on whether the knowledge is perceived to be useful, is relevant to the context, and conforms to the individual's values and beliefs. Organizational cultures that create boundaries to knowledge sharing, by such things as jargon and limited time for cross-function discussion, create the image of knowledge as power, making it less likely to be shared (Kimble, Grenier, \& Goglio-Primard, 2010; Trigland \& Wasko, 2003).

Organizational culture consists of the way that things are done within a workgroup, team, or organization, consisting of explicit items, artifacts, and history (Schein, 2010). Organizational culture is not dissimilar to societal culture, discussed next, except that it is specific to each organization, and the organization can be in one or in several societal cultures (Hofstede, Hofstede, \& Minkov, 2010). In their research, Cameron and Quinn (2011) consider organizational culture to consist of competing values within a firm, all of which are necessary to the appropriate functioning. These values designate four distinct organizational culture types: Clan, Market, Hierarchical, and Adhocracy. Different firm functions require differential emphasis on one of the first four cultural types or perhaps a balanced culture consisting of all four in roughly equal proportions (Cameron \& Quinn, 2011). Defining an organization's specific culture is based on their framework of survey questions, from which the dominant culture can be determined. Each culture is specific, but the optimum is usually a balanced culture with an emphasis on the type that fits the firm context best. Responses are usually obtained using a survey instrument, and the results are plotted on a radar graph to determine which of the four cultures is predominant. Research using other organizational culture dimension are noted (c.f., (Chang \& Lin, 2015), but the Cameron and Quinn framework is chosen due to its utility and ease of measurement and analysis. It is also becoming the standard in management theory research.

A focus on hierarchy culture is important when the organizational environment must be controlled through rules, procedures, and high levels of accountability. Core values of such firms are stability and control. Examples where this culture would predominate is governmental agencies and in firms such as McDonald's restaurants where consistency (in food handling processes) is essential. This culture is also prevalent in the Ford Motor Company with its seventeen levels of management and ensure strict rule adherence (Cameron \& Quinn, 2011). The Market culture works best when the firm's environment is challenged with competitive changes (Ouchi, 1981; Ouchi \& Johnson, 1978; Williamson, 1981). This culture is oriented toward the external rather than on the internal environment of the firm, focusing on the transactions between the firm and external actors, including sales, contractual arrangements, and trades (Cameron \& Quinn, 2011). Cameron and Quin suggest that the core values of such cultures include competitiveness and productivity, and examples of firms with this dominant culture are Phillips Electronics and Xerox, who consider the external environment as being consistently hostile. Insiders use words like "defeating the enemy" or "it's all about the bottom line," because results are the primary focus.

The Clan or collaborate culture is compared to a family environment, in that shared values include cohesion, teamwork, involvement, and empowerment. Cameron and Quinn use Pixar as an example, stating that the firm makes high grossing films, but makes them differently, based on the predominance of clan culture. It puts talented people together, provides adequate resources, and lets "them do their creative work" (p. 47). Loyalty and tradition are valued, and the managers consider commitment and consensus to be extremely desirable. The Adhocracy or create culture arose when the industrial age became the knowledge age (Cameron \& Quinn, 2011). To function successfully in the knowledge environment, a firm must be agile to react to the "hyperturbulent, ever-accelerating conditions that increasingly typify the organizational world" (Cameron \& Quinn, 2011, p. 49). The values in this culture are creativity, adaptation, innovation, and imagination, making knowledge transfer extremely important to this culture. Cameron and Quinn suggest that the adhocracy culture is predominant in Google, Genetech, and most entrepreneurial firms.

The importance of organizational culture in this model is in the motivation for transfer. Using Vroom's expectancy model, motivation for transfer is (a) whether the employee can create the knowledge or successfully transfer the knowledge to the current context, (b) whether there is a reward for this transfer, and (c) whether the reward is valuable for the employee. In firms where the culture is dynamic and there is acceptance and reward for new ideas, it is more likely that knowledge transfer will occur more often. 
Therefore, we propose:

Proposition 2a: In more dynamic and accepting cultures providing rewards for new ideas, e.g. firms with predominantly market or adhocracy cultures, successful knowledge transfer is likely more frequent than in hierarchical or clan cultures.

\subsection{Societal Culture Dimensions}

Societal culture plays a significant role in forming and achieving organizational knowledge management strategies (Bamgboje-Ayodele \& Ellis, 2015). Societal culture is the basic profile of norms, values and institutions of each country (Hofstede, Hofstede, \& Minkov, 2010). Countries are classified and grouped based on their societal cultural profiles. Hofstede defined five major cultural dimensions, and three that are relevant to the model are discussed here: power distance, uncertainty avoidance, and individualism/collectivism.

Power Distance is the extent that inequalities are acceptable within a society (Hofstede, Hofstede, \& Minkov, 2010). It is a fact that there are large inequalities among individuals in all cultures. When looking at power distance, we consider it on a continuum with anchors of high and low power distance. Those with a lower power distance score attempt a more egalitarian society, while higher power distance societies are more willing to accept that there are inequities within it. In many ways, Triandis' (1995) vertical/horizontal dimension parallels Hofstede's (2001) power distance criteria.

The existing literature suggests that power distance has a significant impact on individual and, therefore, on organizational performance (Shahwan, 2017). Those in higher power distance societies are sensitive to hierarchy. They largely respect and/or are afraid of higher positioned managers, usually avoiding behaviors that might challenge them (Shahwan, 2017). Western societies generally are lower power distance, whereas most other societies are higher power distance. Employees working in high power distance societies take their superiors more seriously and obey their orders more than ones in lower power distance societies (Shahwan, 2017). However, Migliore (2011) suggested that newly emerging information and communication technologies (ICTs) can reshape the power distribution in organizations via World Wide Web, causing Hofstede's (Hofstede, Hofstede, \& Minkov, 2010) power distance rankings to be obsolete.

From the information on power distance, we propose:

Proposition 3a: Individuals in lower power distance societies are more likely to accept and transfer knowledge than are those in higher power distance societies, especially if it contradicts those of higher status.

Uncertainty Avoidance. Another important dimension of national culture uncertainty avoidance is a measure of threat perception from unknown situations (Hofstede, Hofstede, \& Minkov, 2010). As with all of Hofstede's dimensions, uncertainty avoidance is on a continuum, with high as one anchor and low as the other. Uncertainty avoidance is related to a reluctance to deal with ambiguity and willingness to embrace change and is different in many ways from risk avoidance (Lucas, 2006).

Individuals deal with ambiguity with differently and, in high uncertainty societies, there are rules and processes for everything that the individual is likely to encounter (Hofstede, Hofstede, \& Minkov, 2010). For example, in the Far East, it is common to have specific rules about meeting those higher or lower in status. If you do not know the status of the other individual or the rules for greeting, then you are considered ill-mannered. In lower uncertainty societies, there are fewer rules about behavior, although norms are still developed; some deviance from norms is more acceptable in these societies (Hofstede, Hofstede, \& Minkov, 2010).

Those in societies where uncertainty avoidance is higher tend to avoid uncertainty by minimizing conflict, rejecting unstable behaviors, and balancing optimal stability with minimal risks (Matusitz \& Musambira, 2013). In lower uncertainty societies, it is more likely that individuals will not shy from taking risks and contemplating new ideas (Matusitz \& Musambira, 2013). From this, we propose:

Proposition 3b: Individuals in lower uncertainty avoidance societies are more likely to accept and transfer knowledge than are those in higher uncertainty avoidance societies, especially if the knowledge creates uncertainty.

Individualism. Within business research, individualism (and collectivism, its opposite) are the most commonly used dimensions of societal culture. As with the other dimensions discussed here, it is a continuum, with individualism as one anchor and collectivism the opposite anchor. In individualism, individual goals are prioritized over group goals, while the opposite exists in collectivism (Hofstede, Hofstede, \& Minkov, 2010). Sharing and consultation are more frequent in collectivistic cultures, due to this prioritization, and group work is more accepted in collectivistic societies than in individualistic societies.

Triandis (1995) used the definition of self to construct a clear distinction between individualism and collectivism within a culture. He found that individualistic culture members are more likely to regard themselves as independent of others, while collectivists are more likely to consider themselves interdependent of others within their in-group. Earley (1993) posited that members of collectivist societies are more likely to view their individual, long-term welfare in terms of in-group success. Therefore, it is more likely that collectivists are more likely to share information with their ingroup members to serve the group before pursing self-interests (Triandis, 1995). However, strong in-group affiliations often coincide with negative feelings toward out-groups (Ashwin, 1996), inter-organizational and intra-organizational sharing may be discouraged by the in-group members (Hutchings \& Michailova, 2006).

Given the information on the individualism dimension, we propose that:

Proposition 3c: Individuals in individualistic societies are more likely to accept and transfer knowledge than are those in collectivistic societies.

Proposition 3d: Individuals in collectivistic societies are more likely to accept and transfer knowledge within their in-group, particularly if the knowledge does not contradict group knowledge. 


\section{CONCLUSION}

In this study, a simplified model of knowledge transfer model has proposed as a framework for understanding the antecedents of knowledge transfer. It is evident that the world is globalizing at a faster pace and companies are experiencing difficulties in finding resources to gain competitive advantage, let alone to sustain one. Future organizations are becoming knowledge-based entities, as Drucker (1988) predicted. Effective knowledge management practices are essential to their operations.

This is a first step in examining intra-organizational transfer of knowledge as a complete system. Knowledge management is a competitive advantage, but it is not technology-based. Both resource and knowledge-based views of the firm acknowledge that individual employee knowledge is a major competitive advantage because it is the most unique, valuable, inimitable, and non-substitutable (c.f., (Barney, 1991; Bou-Llusar \& Segarra-Cipres, 2006). Therefore, knowledge is the most important asset of any individual, organization, or society.

The sharing and transfer of knowledge within organizations can be a more complex process than initially perceived. Hutchings and Michailova (2006) asserted that knowledge sharing is not as natural and apparent as in the idealized knowledge management literature. Hutchings and Michailova (2006) also suggested that the basic assumption common to most of the knowledge management literature is that employees will eagerly share and exchange their knowledge with other employees, or as Sbarcea (2001) noted, the literature assumes the employees will utilize information technology-based automated archives and knowledge databases to research solutions simply because these systems are available. The reality is that inherent organizational cultures may have a natural resistance to information sharing or knowledge transfers, and this phenomenon continues to confound organizational leaders and senior managers today (Hutchings \& Michailova, 2006; Sbarcea, 2001).

However, sharing knowledge is not an easy task because of technological, personal, cultural, structural and political considerations (Winkelen \& McKenzie, 2012). Individual cognition and organizational culture plays an important role in knowledge sharing but have not been well explored within the knowledge management literature. Knowledge management practices must consider the most efficient and effective techniques to capture, manage, store, and share individual and organizational knowledge for better decision-making processes.

As Levitt (1983) predicted, enhancing technologies and our modernizing societies could lead to a convergence of customers' needs and desires. This could result in more global companies designing and implementing universal marketing and advertising strategies. Hence, effective and multidimensional knowledge sharing is an indispensable element of every organizational management practice in today's global economy. Similarly, each society or nation may present completely different mindset patterns to deal with in terms of what is shared, how it is shared, and when (Hofstede, Hofstede, \& Minkov, 2010). In this process, cultural dimensions of each society play significant role in knowledge sharing, processing, and enhancement.

Organizations are replicators that function as moral circles and thrive to survive in competing environments. Companies which are successful in creating, managing, distributing, and sharing their organizational knowledge will be the successful ones in free trade markets. Their survival requires providing better facilities, environments, and infrastructure to their employees to allow them to acknowledge, transfer, and manage their knowledge. The prerequisite of creating such an environment is to appreciate the individual differences of each employee.

Davenport and Prusak (2000) suggested that senior leaders and managers should assess their organizational culture before deploying new knowledge management initiatives. Bock (1999), Nonaka and Takeuchi (1995), Rastogi (2000), and von Krogh, Ichijo, and Nonaka (2000) maintained that organizational culture should be the central focus of new knowledge management initiatives. While many researchers recognized the crucial nature of organizational culture as an important factor in effective knowledge management, there is little consensus relative to creating an effective culture for knowledge management. In effect, do knowledge cultures facilitate the growth, development and maturation of effective knowledge management systems and processes? Davenport and Prusak (2000)indicated that business culture assumes the determining role in successfully managing and transferring knowledge. Moreover, the researchers suggested that if leaders and managers spent more than a third of their time and budget on technology-related issues, then they were apt to neglect the more important issues including organizational culture.

Future research in this area is ongoing. There are multiple opportunities to look at environmental assistance to knowledge transfer, types of knowledge necessary for each industry, knowledge transfer between various levels of the organization and across cultural segments of the firm, and the ways to determine which individual possesses each type of knowledge. For example, one study investigated individual knowledge transfer in China (Ma, Wu, Dong, \& Qi, 2014), and we believe that more studies in these areas would be beneficial to the understanding of knowledge transfer at the micro level. Park and Sung (2017) found that social networking quality comes through person to person interaction and is useful in improving creativity and productivity; however, social network knowledge diversity is found online and improved creativity. Pauluzzo and Cagnina (2017) examined cultural competencies in knowledge transfer in their case study, proposing a framework to help transfer.

Understanding the functionality of knowledge management is an important aspect of management, and communities of practice can be useful in knowledge acquisition, retention, and transfer. Lave and Wenger (1991/2003) first coined the term community of practice to signify those activities in which the participants share and exchange knowledge, learn together, and achieve basic understandings relative to their work, lives, and their community. Hildreth, Kimble, and Wright (2000) considered these communities as a means to appraise and understand organizational knowledge as well as social relationships. Further, Manville and Foote (1996) noted that the members are typically united to each other in common causes such as problem-solving endeavors, and strategic interventions, thereby facilitating information exchange, while serving as a repository of knowledge. Consequently, these communities of practice function as the exchange mechanism for information sharing and knowledge transfers, as well as the designated organizational vehicle for knowledge creation and the development of new ideas (Hildreth, Kimble, \& Wright, 2000). However, communities of practice are not a panacea. Regardless of management direction or enthusiastic top management team support, Stamps (1997) warned that no one can force individuals to acquire, maintain, or exchange knowledge, which is an inherent weakness within these communities. 


\section{REFERENCES}

Alavi, M. M., \& Leidner, D. E. (2001). Knowledge management and knowledge management systems: Conceptual foundations and research issues. MIS Quarterly, 25(1), 107-136.

Argote, L., Ingram, P., Levine, J. M., \& Moreland, R. L. (2000). Knowledge transfer in organizations: Learning from the experience of others. Organizational Behavior and Human Decision Processes, 82, 1-8.

Argyris, C., \& Schon, D. A. (1978). Organizational learning: A theory of action perspective. Reading, MA: Addison-Wesley.

Ashwin, S. (1996). Forms of collectivity in a non-monetary society. Sociology: The Journal of the British Sociological Association, 30(1), 21-39.

Bamgboje-Ayodele, A., \& Ellis, L. (2015). Knowledge Management and the Nigerian Culture-A round peg in a square hole? The African Journal of Information Systems, 7(1), 1-20.

Barney, J. (1991). Firm resources and firm competitive advantage. Journal of Management, 17(1), 203-227.

Bassi, L. (1997). Harnessing the power of intellectual capital. Training \& Development, 51(12), 25-30.

Baumeister, R. F., \& Leary, M. R. (1995). The need to belong: Desire for interpersonal attachments as a fundamental human motivation. Psychological Bulletin, 117, 497-529.

Becerra-Fernandez, I., \& Sabherwal, R. (2001). Organizational knowledge management: A continency perspective. Journal of Management Information Systems, 18(1), 23-55.

Berger, P. L., \& Luckmann, T. (1966). The social construction of reality: A treatise in the sociology of knowledge. Doubleday: New York.

Bhagat, R. S., Kedia, B. L., Harveston, P. D., \& Triandis, H. C. (2002). Cultural variations in the cross-border transfer of organizational knowledge: An integrative framework. Academy of Management Review, 27(2), 204-221.

Bock, F. (1999, March/April). The intelligent approach to knowledge management: Viewing KM in terms of content, culture, process, and infrastructure. Knowledge Management Review, 7, 22-25.

Bou-Llusar, C. J., \& Segarra-Cipres, M. (2006). Strategic knowledge transfer and its implications for competitive advantage: An integrative conceptual framework. Journal of Knowledge Management, 10(4), 100-112.

Branch, R. M. (1997). Educational technology frameworks that facilitate culturally pluralistic instruction. Educational Technology, 37(2), 3841.

Brauner, E., \& Becker, A. (2006). Beyond knowledge sharing: The management of transactive knowledge systems. Knowledge and Process Management, 13(1), 62-71.

Buehrer, R. E., Senecal, S., \& Bolman, E. P. (2005). Sales force technology usage - reasons, barriers, and support: An exploratory examination. Industrial Marketing Management, 34, 389-398.

Cameron, K. S., \& Quinn, R. S. (2011). Diagnosing and changing organizational culture: Based on the competing values framework (3 b.). Jossey-Bass.

Carrier, J., \& Kendall, I. (1995). Professionalism and interprofessionalism in health and community care: Some theoretical issue. J. C. P. Owens içinde, Interprofessional issues in community and primary health care. London: MacMillan.

Chang, C. L.-h., \& Lin, T.-C. (2015). The orle of organizational culture in the knowledge management process. Journal of Knowledge Management, 19(3), 433-455.

Chou, M. M., Hong, Y., \& Chiu, C. (2012). Essentializing race: Its implication on racial categorization. Journal of Personality and Social Psychology, 104, 619-634.

Cohen, W. M., \& Levinthal, D. A. (1990). Absorptive capacity: A new perspective on learning and innovation. Administrative Science Quarterly, 35(1), 128-152.

Conner, K. R., \& Prahalad, C. K. (1996). A resource based theory of the knowledge versus opportunism. Organization Science, 7(5), 477-501.

Davenport, T. H., \& Prusak, L. (2000). Working knowledge: How organizations manage what they know. Boston, MA: Harvard Business School Press.

Davenport, T. H., De Long, D. W., \& Beers, M. C. (1998). Successful knowledge management projects. Sloan Management Review, 39(2), 4357.

De Long, D. W., \& Fahey, L. (2000). Diagnosing cultural barriers to knowledge management. Academy of Management Executive, 14(4), 113128.

DeSouza, K. C. (2003). Knowledge management barriers: Why the technology imperative seldom works. Business Horizons, 46(1), $25-29$.

Diakoulakis, I. E., Georpopoulos, N. B., Koulouriotis, D. E., \& Emeris, D. M. (2004). Towards a holistic knowledge management model. Journal of Knowledge Management, 8(1), 32-46. 
Drucker, P. F. (1988). The Coming of the New Organization. Harvard Business Review on Knowledge Management (s. 1-19). içinde Harvard Business School Press.

Drucker, P. F. (1994). The age of social transformation. Atlantic Monthly, 274(5), s. 53-80.

Drucker, P. F. (1999). Management challenges for the 21st century. New York:: Harperbusiness.

Drucker, P. F. (2010). The new realities (Revised b.). New Brunswick, NJ: Transaction Publishers.

Du Plessis, M. (2005). Drivers of knowledge management in the corporate environment. International Journal of Information Management, $02,193-202$.

Earl, M. J. (2001). Knowledge management strategies: Toward a taxonomy. Journal of Management Information Systems, 18(1), 215-233.

Earley, P. C. (1993). East meets west meets mideast: Further explorations of collectivistic and individualistic work groups. Academy of Management Journal, 36(2), 319-348.

Ekbia, H., \& Hara, N. (2008). The quality of evidence in knowledge management research: Practitioner vs scholarly literature. Journal of Information Science, 34(1), 110-126.

Evetts, J. (1999). Professionalisation and professionalism: issues for interprofessional care. Journal of Interprofessional Care, 13(2), 119-12.

Fischer, R. (2011). Cross-cultural training effects on cultural essentialism beliefs and cultural intelligence. International Journal of Intercultural Relations, 35, 767-775.

Foa, E. B., \& Foa, U. G. (1980). Social exchange. Springer US.

Frappaolo, C. (2006). Knowledge Management. North Mankato, MN: Capstone.

Gardner, W. L., Pickett, C. L., \& Brewer, M. B. (2000). Social exclusion and selective memory: How the need to belong influences memory for social events. Personality and Social Psychology Bulletin, 26, 486-496.

Gelman, S. A. (1988). The development of induction within natural kind and artifact categories. Cognitive Psychology, 20, 65-95.

Gelman, S. A. (2003). The essential child: Origins of essentialism in everyday thought. New York: Oxford University Press.

Gourlay, S. (2006). Towards conceptual clarity for tacit knowledge: A review of empirical studies. Knowledge Management Research and Practice, 4(1), 60-69.

Grant, R. M. (1996a). Prospering in dynamically-competitive environments: Organizational capability as knowledge integration. Organization Science, 7(4), 375-387.

Grant, R. M. (1996b). Toward a knowledge-based theory of the firm. Strategic Management Journal, 17(2), 109-122.

Grayson, C. J., \& O'Dell, C. S. (1998). Mining your hidden resources. Across the Board, 35, s. 23-28.

Griffiths, P. D., \& Remenyi, D. (2008). Aligning knowledge management with competitive strategy: A framework. (125-134, Dü.) Electronic Journal of Knowledge Management, 6(2). http://ejkm.com/volume6/issue2 adresinden alındı

Hackett, B. (2000). Beyond knowledge management: New ways to work and learn. New York: The Conference Board.

Hansen, M. T., \& Nohria, N. (1999). What's your strategy for managing knowledge? Harvard Business Review, 77(2), 106-116.

Hendricks, P. (1999). Why share knowledge? The influence of ICT on the motivation for knowledge sharing. Knowledge and Process Management, 6(2), 91-100

Hildreth, P., Kimble, C., \& Wright, P. (2000). Communities of practice in the distributed international environment. Journal of Knowledge Management, 4(1), 27-38.

Hofstede, G., Hofstede, G. J., \& Minkov, M. (2010). Culture and Organizations: Software of the mind. New York: McGraw-Hill.

Hudson, B. (2002). Interprofessionality in health and social care: The Achilles' heel of partnership? Journal of Interprofessional Care, 16(1), 717.

Hutchings, K., \& Michailova, S. (2006). Facilitating knowledge sharing in Russian and Chinese subsidiaries: The role of personal networks and group membership. International Journal of Emerging Markets, 1(1), 21-34.

Jayaratne, T. Y., Ybarra, O., Sheldon, J. P., Brown, T. N., Feldbaum, M., Pfeffer, C. A., \& Petty, E. M. (2006). White Americans' genetic lay theories of race differences and sexual orientation: Theft relationship with prejudice toward Blacks, and gay men, and lesbians. Group Processes and Intergroup Relations, 19, 77-94.

Kashima, Y. (2014). Meaning, grounding, and the construction of social reality. Asian Journal of Social Psychology, 17, 81-95.

Keen, P., \& Mackintosh, R. (2001). The freedom economy: Gaining the M-commerce edge in the era of the wireless Internet. Berkeley, CA: Osborne/McGraw-Hill. 
Kimble, C., Grenier, C., \& Goglio-Primard, K. (2010). Innovation and knowledge sharing across professional boundaries: Political interplay between boundary objects and brokers. International Journal of Information Management, 30(5), 437-444.

King, W. R. (2009). Knowledge management and organizational learning. Annals of Information Systems, 4, 3-13.

KMPG. (2000). Knowledge management research UK: www.providersedge.com/docs/km_articles/kpmg_km_research_report_2000.pdf adresinden alındı

Kucharska, W., \& Kowalczyk, R. (2016). Trust, Collaborative Culture and Tacit Knowledge Sharing in Project Management-a Relationship Model. Proceedings of the 13th International Conference on Intellectual Capital, Knowledge Management \& Organisational Learning: ICICKM (s. 159-166). unknown: ICICKM. https://www.researchgate.net/profile/Wioleta_Kucharska3/publication/309284422_Trust_Collaborative_Culture_and_Tacit_Knowledge_S haring_in_Project_Management_-_a_Relationship_Model/links/580794ab08ae07cbaa54301f.pdf adresinden alındı

Lang, J. (2001). Managerial concerns in knowledge management. Journal of Knowledge Management, 5(1), 43-59.

Lave, J., \& Wenger, E. (1991/2003). Situated learning: Legitimate peripheral participation. New York: Cambridge University Press.

Leonard-Barton, D., \& Sensiper, S. (1998). The role of tacit knowledge in group innovation. California Management Review, 40, $112-132$.

Lin, C., Yeh, J. Y., \& Tseng, S. M. (2005). Case study on knowledge management gaps. Journal of Knowledge Management, 9(3), 36-50.

Lucas, L. M. (2006). The role of culture on knowledge transfer: the case of the multinational corporation. The learning organization, 13(3), 257-275.

Lucier, C. \&. (1997). Why knowledge programs fail. Strategy and Business, ?, 14-28.

Lukas, L. M., \& Ogilvie, D. T. (2006). Things are not always what they seem: How reputations, culture, and incentives influence knowledge transfer. Learning Organization, 13(1), 7-24.

Ma, Z., Wu, J., Dong, W., \& Qi, L. (2014). What matters for knowledge sharing in collectivistic cultures? Empirical evidence from China. Journal of Knowledge Management, 18(5), 1004-1019.

Manville, B., \& Foote, N. (1996). Harvest your workers' knowledge. Datamation, 42(12), 78-80.

Martensson, M. (2000). A critical review of knowledge managmeent as a mangement tool. Journal of Knowledge Management, 4(3), 204216.

Matusitz, J., \& Musambira, G. (2013). Power distance, uncertainty avoidance, and technology: analyzing Hofstede's dimensions and human development indicators. Journal of Technology in Human Services, 31(1), 42-60.

McCann, J. E., \& Syke, J. H. (2004). Strategically integrated knowledge management initiatives. Journal of Knowledge Management, 8(1), 4763

McDermott, R. (1999). Why information technology inspired but cannot deliver knowledge management. California Management Review, 38(1), 24-59.

Medin, D. L. (1989). Concepts and conceptual structure. American Psychologist, 44, 1469-1481.

Morton, T. A., \& Postmes, T. (2009). When differences become essential: Minority essentialism in response to majority treatment. Personality and Social Psychology Bulletin, 35, 656-668.

Morton, T. A., Postmes, T., Haslam, S. A., \& Hornsey, M. J. (2009). Theorizing gender in the face of social change: Is there anything essential about essentialism? Journal of Peronality and Social Psychology, 96, 653-664.

Nonaka, I. (1994). A dynamic theory of organizational knowledge creation. Organization Science, 5(1), 14-37.

Nonaka, I., \& Konno, N. (1998). The concept of 'ba': Building a foundation for knowledge creation. California Management Review, 40, 4054

Nonaka, I., \& Takeuchi, H. (1995). The knowledge creating company: How Japanese companies create the dynamics of innovation. Oxford: Oxford University Press.

Nonaka, I., \& Takeuchi, H. (2004). Hitotsubashi on knowledge management. Hoboken, NJ: John Wiley \& Sons.

O'Dell, C., \& Grayson, C. J. (1998). If only we knew what we know: Identification and transfer of internal best practices. California Management Review, 40(3), 154-174

Ouchi, W. G. (1981). Theory Z: How American business can meet the Japanese challenge. Reading, MA: Addison-Wesley.

Ouchi, W. G., \& Johnson, J. (1978). Types of organizational control and their relationship to emotional well-being. Administrative Science Quarterly, 23, 293-317.

Pan, S. L., \& Scarbrough, H. (1999). Knowledge management in practice: An exploratory care study of Buckland Labs. Technology Analysis and Strategic Management, 11(3), 359-374. 
Park, J. Y., \& Sung, C.-S. (2017). Is social networking a waste of time? The impact of social network and knowledge characteristics on job performance. Knowledge Management Research and Practice, 15(4), 560-571.

Pauluzzo, R., \& Cagnina, M. R. (2017). Bridging the divide: Intercultural competences to reconcile the knowledge transfer dilemma in multinational contexts. Knowledge Management Research and Practice, 15(4), 542-550.

Penrose, E. (1959). The theory of the growth of the firm. Oxford: Blackwell.

Polanyi, M. (1958). Personal knowledge. Chicago: University of Chicago Press.

Polanyi, M. (1966). The tacit dimension. Garden City, NY: Doubleday.

Polanyi, M. (1969). Knowing and being. Chicago: University of Chicago Press.

Popper, K. (1979). Objective knowledge: An evolutionary approach. Oxford: Oxford University Press.

Prentice, D. A., \& Miller, D. T. (2006). Essentializing differences between women and men. Psychological Science, 17, $129-135$.

Rastogi, P. N. (2000). Knowledge management and intellectual capital: The new virtuous reality of competitiveness. Human Systems Management, 19(1), 39-49.

Reis, T., \& Clohesy, S. (1999). Unleashing new resources and entrepreneurship for the commond good: A scan, synthesis, and scenario for action. Battle Creek, MI: W.K. Kellogg Foundation.

Rescher, N. (1998). Communicative pragmatism and other philosophical essays on language. Lanham, MD: Rowman \& Littlefield, Publishers.

Ringberg, T., \& Reihlen, M. (2008). Towards (sic) a socio-cognitive approach to knowledge transfer. Journal of Management Studies, 45(5), 912-935.

Sankowska, A. (2016). Trust, knowledge creation and mediating effects of knowledge transfer processes. Journal of Economics \& Management, 23, 33-44.

Sbarcea, K. (2001). The mystery of knowledge management. New Zealand Management, 48(10), 33-35.

Scarbrough, H., \& Swan, J. (1999). Case studies in knowledge management. London: IPD.

Schein, E. (2010). Organizational culture and leadership (4 b.). New York: John Wiley \& Sons.

Shahwan, U. (2017). Relationship Between Power Distance and Employee Performance in Multi-National Organizations. Skyline Business Journal, 12(1), 48-54.

Stamps, D. (1997). Communities of practice: Learning is social. Training is irrelevant? Training, 34(2), 34-42.

Stewart, T. A. (1997). Intellectual capital: The new wealth of organizations. New York: Doubleday.

Storey, J., \& Barnett, E. (. (2000). Knowledge management initiatives: Learning from failure. Journal of Knowledge Management, 4(2), 145156.

Sveiby, K. E. (1999). The new organizational wealth. San Francisco: Berrett-Koehler.

Syed-Ikhsan, S. O., \& Rowland, F. (2004). Knowledge management in a public organization in Malaysia: Do people really share? Journal of Knowledge Management, 8(2), 95-111.

Tobin, D. (1997). The knowledge enabled organization. New York: AMACOM.

Triandis, H. C. (1994). Cross-cultural industrial and organizational psychology. H. C. Triandis, M. D. Dunnette, \& L. M. Hough (Dü) içinde, Handbook of industrial and organizational psychology (2 b., Cilt 4, s. 103-172). Consulting Psychologists Press.

Triandis, H. C. (1995). Individualism and collectivism. Boulder, CO: Westview Press.

Trigland, R., \& Wasko, M. M. (2003). Integrating knowledge through information trading: Examining the relationship between boundary spanning communication and individual performance. Decision Sciences, 34(2), 261-286.

von Krogh, G., Ichijo, K., \& Nonaka, I. (2000). Enabling knowledge creation: How to unlock the mystery of tacit knowledge and release the power of innovation. New York: Oxford University Press.

von Krogh, G., Ichijo, K., \& Nonaka, I. (2000). Enabling knowledge creation: How to unlock the mystery of tacit knowledge and release the power of innovation. New York: Oxford University Press.

Wadell, C., Bjork, J., \& Magnusson, M. (2014). How do R\&D employees use their social networks to acquire user information? Journal iof Knowledge Management, 18(5), 919-936.

Weick, K. (2001). Making sense of the organization. Malden, MA: Blackwell Publishing

Wenger, E. (1998). Communities of practice: Learning, meaning, and identity. Cambridge: Cambridge University Press.

Williamson, O. E. (1981). The economics of organization: The transaction cost approach. American Journal of Sociology, 87(3), 548-577. 
Winkelen, C., \& McKenzie, J. (2012). An Exploration of Epistemic Culture As a Barrier to Knowledge Flows. European Conference on Knowledge Management, 6. Cartagena Spain.

Wright, P. M., McMahan, G. C., \& McWilliams, A. (1994). Human resources and sustained competitive advantage: A resource-based perspective. International Journal of Human Resource Management, 5(2), 301-326.

Yolles, M. (2006). Organizations as complex systems: An introduction to knowledge cybernetics. Greenwich, CT: Information Age Publishing. 